\title{
Nitric oxide induced by Indian ginseng root extract inhibits Infectious Bursal Disease virus in chicken embryo fibroblasts in vitro
}

\author{
Bhaskar Ganguly ${ }^{1,2^{*}}\left(\mathbb{D}\right.$, Vijaypillai Umapathi ${ }^{1,3}$ and Sunil Kumar Rastogi $i^{1}$
}

\begin{abstract}
Infectious Bursal Disease is a severe viral disease of chicken responsible for serious economic losses to poultry farmers. The causative agent, Infectious Bursal Disease virus, is inhibited by nitric oxide. Root extract of the Indian ginseng, Withania somnifera, inhibits Infectious Bursal Disease virus in vitro. Also, Withania somnifera root extract is known to induce nitric oxide production in vitro. Therefore, the present study was undertaken to determine if the inhibitory activity of Withania somnifera against Infectious Bursal Disease virus was based on the production of nitric oxide. We show that besides other mechanisms, the inhibition of Infectious Bursal Disease virus by Withania somnifera involves the production of nitric oxide. Our results also highlight the paradoxical role of nitric oxide in the pathogenesis of Infectious Bursal Disease.
\end{abstract}

Keywords: Aminoguanidine, Infectious Bursal Disease virus, Nitric oxide, Pathogenesis, Withania somnifera

\section{Introduction}

Infectious Bursal Disease (IBD) is an acute, highly contagious, and immunosuppressive disease of young chicken, caused by double-stranded RNA virus belonging to the genus Avibirnavirus of family Birnaviridae. It is characterized by the destruction of dividing lymphoid cells in the bursa of Fabricius causing cytolysis leading to immunosuppression in addition to severe economic losses due to impaired growth, death, and excessive condemnations of carcasses because of skeletal muscle hemorrhages [9]. The virus is evolutionarily related to rotaviruses (Reoviridae) and picornaviruses (Picornaviridae) (Dalton and Rodriguez, [8]). The virus can be adapted to grow and produce cytopathic effects in chicken embryo fibroblasts (CEF) [25].

Nitric oxide (NO) has been shown to inhibit a number of viruses, including Herpes Simplex virus type 1 [7], Ectromelia virus, Vaccinia virus [15], Vesicular Stomatitis virus [5], and murine Friend leukemia retrovirus [1]. Lin et al. [20] have reported the inhibitory effect of NO on

\footnotetext{
* Correspondence: vetbhaskar@gmail.com

${ }^{1}$ Animal Biotechnology Center, Department of Veterinary Physiology and Biochemistry, College of Veterinary \& Animal Sciences, G. B. Pant University of Agriculture \& Technology, Pantnagar 263145, India

${ }^{2}$ Clinical Research Division, Ayurvet Limited, Katha 173205, India

Full list of author information is available at the end of the article
}

Japanese encephalitis viral RNA synthesis, viral protein accumulation, and virus release from infected cells. NO also inhibited the replication cycle of Encephalomyocarditis virus [14], Coxsackie virus [26], Marek's diseases virus [27], Respiratory Syncytial virus [3] and Severe Acute Respiratory Syndrome virus [2]. NO combines with superoxide radical to produce peroxynitrite radical $\left(\mathrm{ONOO}^{-}\right)$that reacts with capsid proteins on Coxsackie virus, leading to the inhibition of viral entry into cells [22]. NO also inhibits a variety of transcription factors [13] and viral proteinases [6] that are required for viral replication. Takhampunya et al. [23] reported the inhibitory effect of NO on Dengue virus infection, partly via the inhibition of the RdRp (RNA-dependent RNA polymerase enzyme) activity, which then down-regulates viral RNA synthesis. Jena [17] could demonstrate the inhibition of IBD virus (IBDV) replication in CEF by NO.

Previously, we have shown profound inhibition of IBDV in CEF by root extract of the Indian ginseng, Withania somnifera (Linn.) Dunal (WS); however, the mechanism of inhibition was not clear [11]. WS is a well-known inducer of NO. Iuvone et al. [16] found that WS significantly increased NO production in vitro through concentration-dependent up-regulation of inducible nitric oxide synthetase ( $i$ NOS) expression. Hence, 


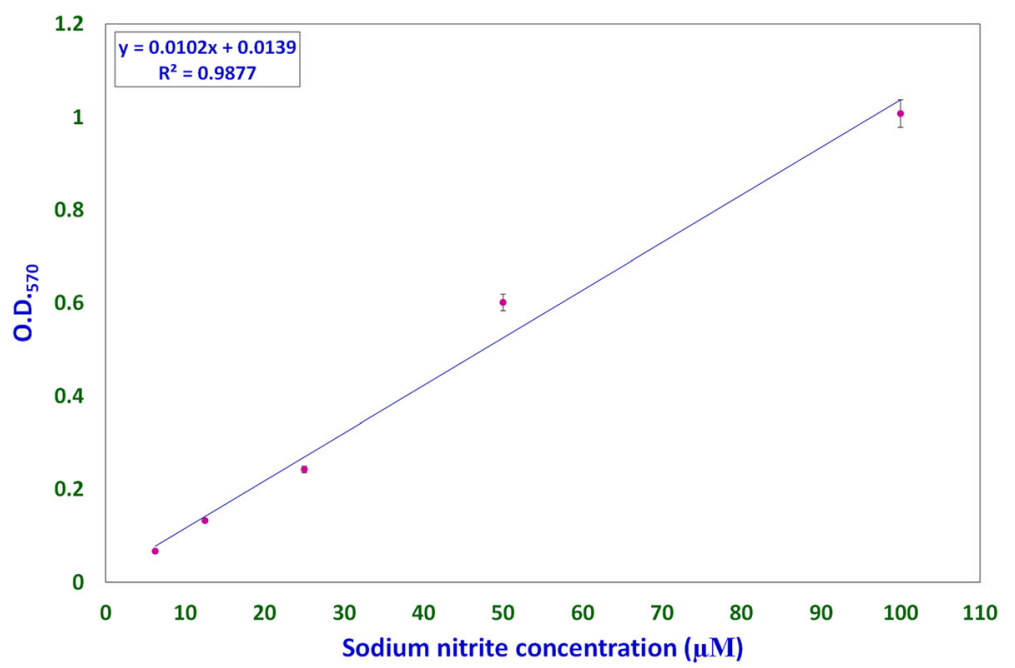

Fig. 1 Sodium nitrite standard curve for determination of nitric oxide concentration. Standard curve for determining and expressing nitric oxide concentrations was derived using solutions of known concentration of sodium nitrite. Each concentration of sodium nitrite was assayed thrice independently, and the mean of the three observations was used to obtain the standard curve

the present investigation was undertaken to ascertain the production of $\mathrm{NO}$ as an underlying mechanism of the inhibitory effect of WS against IBDV in CEF.

\section{Materials and methods}

\section{Cell culture}

Nine - Eleven days old, embryonated chicken eggs, were obtained from the Instructional Poultry Farm, G. B. Pant University of Agriculture and Technology, and used for obtaining primary monolayer cultures of CEF as described previously by Villegas [24]. The fibroblasts were resuspended in EMEM with 10\% fetal bovine serum, and the cell concentration was adjusted to a final seeding rate of $1 \times 10^{7}$ cells $/ \mathrm{mL}$ of the media. About $3 \mathrm{~mL}$ and $100 \mu \mathrm{L}$ of the seed were added per well in 6-well and 96-well tissue culture plates, respectively. The plates were incubated at $37{ }^{\circ} \mathrm{C}$ with $5 \% \mathrm{CO}_{2}$ tension for $24 \mathrm{~h}$ to obtain the monolayer.

\section{Virus}

Pre-confirmed, CEF-adapted IBD virus of strain UA-Bz 1 , passage 6 , available in the department was used in this study. Unless stated otherwise, the CEF were infected with the virus at a multiplicity of infection of 0.1 .

\section{Withania somnifera Root extract}

Methanol: chloroform: water:: 12:5:3 (MCW) extract of roots of Withania somnifera roots obtained and characterized as described previously [12] was used in the present study at a concentration of $160 \mu \mathrm{g} / \mathrm{mL}$ pre-determined to be non-cytotoxic to CEF (data not shown).

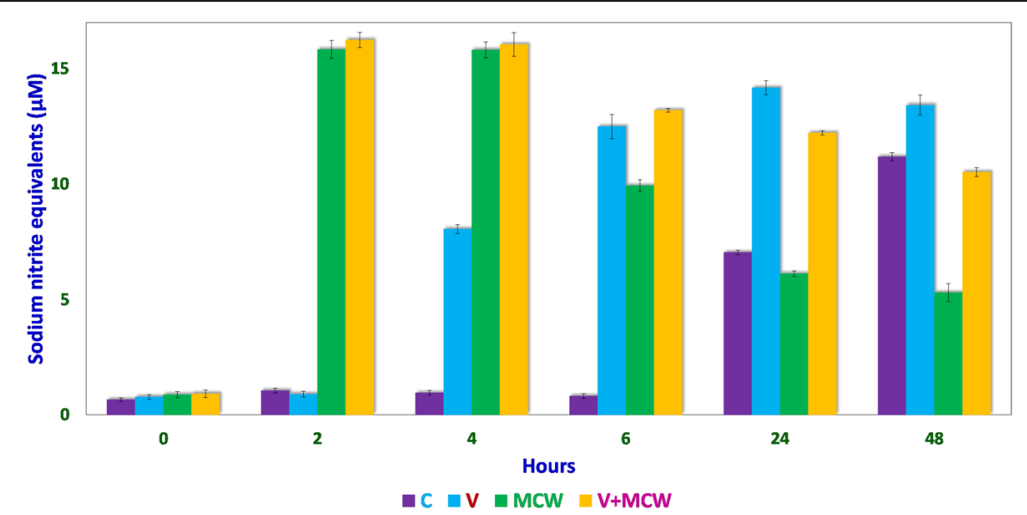

Fig. 2 Results of Griess test. Nitric oxide concentrations, expressed as micromolar $(\mu \mathrm{M})$ sodium nitrite-equivalents, at various intervals of time in control $(C)$, virus-infected $(V)$, uninfected and extract-treated CEF (MCW), and virus-infected and extract-treated $(V+M C W) C E F$ have been shown for comparison 


\section{Nitric oxide assay}

\section{Griess test}

CEF monolayers were grown in 6-well cell culture plates and upon reaching $80-90 \%$ confluence, they were infected with IBDV with or without MCW extract treatment. $0.75 \mathrm{~mL}$ of the culture medium was withdrawn from each group at $0,2,4,6,24$ and $48 \mathrm{~h}$ and transferred to five wells $(150 \mu \mathrm{L}$ each) of a 96-well plate. The volume withdrawn from the 6-well plate was made up with medium of matching MCW extract concentration. To each well of the 96-well plate, $100 \mu \mathrm{L}$ of Griess reagent was added and allowed $30 \mathrm{~min}$ for color development, following which the plate was read at $570 \mathrm{~nm}$. Concentrations of nitric oxide were expressed in terms of sodium nitrite-equivalents, obtained by using a sodium nitrite standard curve.

\section{Effect of aminoguanidine supplementation}

Aminoguanidine is a known inhibitor of inducible nitric oxide [21]. First, the non-cytotoxic dose of aminoguanidine for CEF cells was determined by MTT [3-(4,5dimethythiazol-2-yl)-2,5-diphenyl tetrazolium bromide] assay, as described elsewhere [10]. Thereafter, aminoguanidine, at its non-cytotoxic dose, was used to treat IBDV-infected CEF at $-2,0,2,4$ or $6 \mathrm{~h}$ post-infection (HPI) in the presence or absence of MCW extract. The plate was allowed to incubate and MTT assay was performed $48 \mathrm{HPI}$.

\section{Statistical analyses}

All statistical operations were performed in MS-Excel 2007. Statistical comparisons between different groups were made by analysis of variance (ANOVA) followed by post hoc Tukey test performed with Daniel's XL Toolbox $v$.6.53. Unless stated otherwise, all statistical inferences were drawn at $p<0.01$.

\section{Results and discussion}

Nitric oxide levels were determined on the basis of a sodium nitrite standard curve $(y=0.0102 x+0.0139, R[2]=$ 0.9877; Fig. 1) using Griess reagent. Nitric oxide levels, expressed as micromolar equivalents of sodium nitrite, at different time intervals are shown in Fig. 2. MCW extract, alone or with the virus, caused a rapid and significant $(p<0.01)$ increase in NO levels within $2 \mathrm{~h}$ of extract supplementation. The increased levels of $\mathrm{NO}$ declined significantly faster in the uninfected CEF than in the virus-infected CEF. CEF infected with the virus and left untreated showed a more gradual but persisting increase in NO levels. These findings suggest that MCW extract causes a rapid rise in NO levels in CEF that is inhibitory to the virus. Our findings are supported by previous findings of Jena [17], where it has been shown that NO is inhibitory to IBDV in vitro. It has been stated

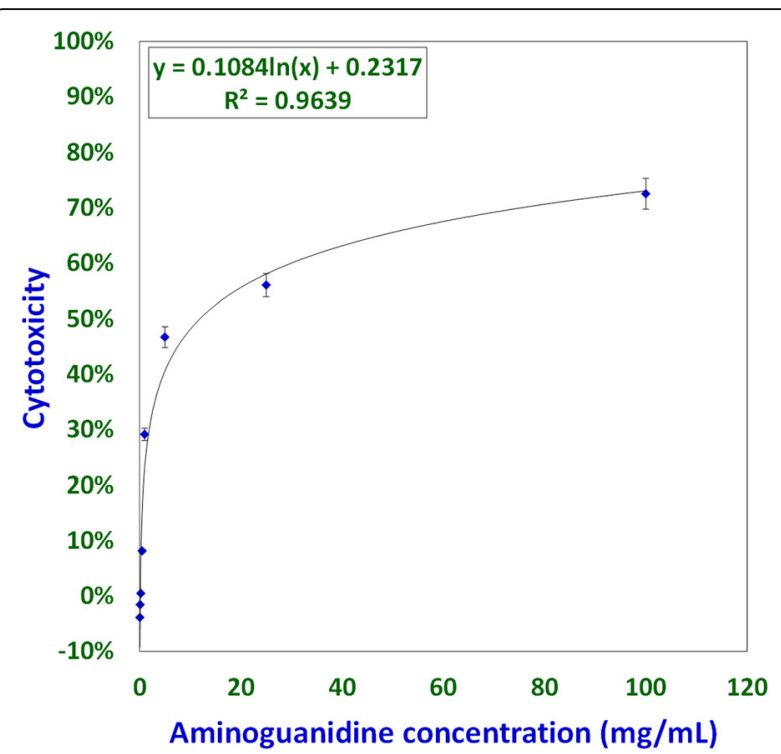

Fig. 3 Determination of non-cytotoxic concentration of aminoguanidine for CEF; CEF growing in 96-well plates were treated with different concentrations of aminoguanidine, four wells per concentration. The test was repeated thrice independently and the mean of the values was used for determining the concentration-dependent cytotoxicity of aminoguanidine. The non-cytotoxic dose and median lethal dose were calculated from the standard curve

that IBDV infection alone is insufficient to induce NO production in CEF in vitro; cytokines or chemical donors are essentially required to achieve NO production in CEF [17]. Our results establish that IBDV infection induces production of NO by CEF. Moreover, WS can induce NO in CEF irrespective of IBDV infection. Control CEF also showed a late rise in NO levels; this may possibly have been due to senescence-associated changes.

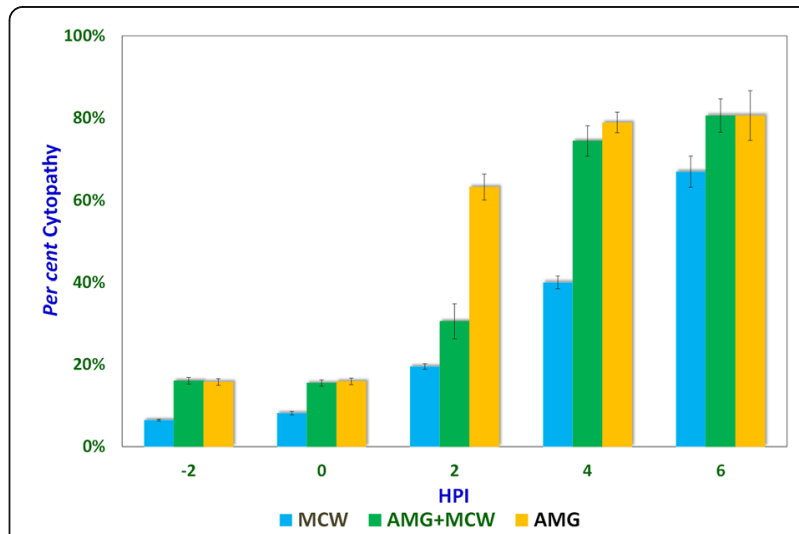

Fig. 4 Effect of aminoguanidine supplementation on cytopathy induced by IBDV in CEF; virus-infected CEF were treated with either extract (MCW), aminoguanidine (AMG), or both aminoguanidine and MCW extract (AMG + MCW) at various intervals of time. Percent virus-induced cytopathy at $48 \mathrm{HPI}$ has been shown for comparison 
Studies involving aminoguanidine (AMG), a known inhibitor of NO induction, were undertaken to further elucidate the interplay of NO, MCW extract, and IBDV. The non-cytotoxic dose of AMG was determined at $118 \mu \mathrm{g} / \mathrm{mL}$ whereas the $L D_{50}$ was determined at about $11.88 \mathrm{mg} / \mathrm{mL}$ (Fig. 3). For the ease of dilution and dispensing, AMG was supplemented at a concentration of $100 \mu \mathrm{g} / \mathrm{mL}$ that was well within the range of concentrations known to inhibit inducible NO [21]. IBDVinduced cytopathy increased significantly with the delay in MCW supplementation (Fig. 4). The presence of AMG significantly attenuated the virus-inhibitory activity of MCW. These findings of AMG supplementation studies suggest that anti-IBDV activity of MCW extract involves NO production, which gets diminished in the presence of AMG. Nonetheless, MCW extract must be capable of inhibiting IBDV in vitro through additional mechanisms, not necessarily involving induction of $\mathrm{NO}$, as some inhibition of the virus by MCW extract occurred even in the presence of AMG.

It could be seen that presence of AMG early during infection itself was inhibitory to the virus, suggesting that either AMG is capable of exerting direct effects on the virion or that $\mathrm{NO}$ is needed early during infection for the pathogenesis of IBDV in vitro. Indeed, NO is required early during infection by IBDV. NO plays a dual role in the pathogenesis of IBD. Infection by IBDV causes the host to produce NO, which initially helps the virus but later turns detrimental to it. Khatri et al. [19] reported that bursal macrophages were susceptible to IBDV infection and macrophage infection was associated with induction of $i$ NOS. Macrophages from the infected chicken also showed up-regulated cytokine gene expression and increased production of NO. Such activated macrophages inhibit the proliferation of splenocytes in response to mitogenic stimulation. Inhibition of the mitogenic response is likely mediated by $\mathrm{NO}$ and this $\mathrm{T}$ cell suppressive activity helps in virus survival. NO attracts and enhances infiltration of inflammatory cells in the bursa, promoting local tissue damage, which initially helps in the spreading of the virus and later helps in clearing the pathogen [18]. In vivo, the infection with virulent IBDV can result in detectable NO levels in serum and the immunosuppressed chicken that fail to induce NO have more severe disease and a higher degree of virus replication [4].

In conclusion, we show that Withania somnifera root extract induces early production of nitric oxide in chicken embryo fibroblasts, which reduces IBDVinduced cytopathy. However, induction of nitric oxide is not the sole mechanism of inhibition of IBDV-induced cytopathy by Withania somnifera. Although nitric oxide production by Withania somnifera inhibits cytopathy, the inhibition of nitric oxide production, by aminoguanidine, early during infection also inhibits IBDV-induced cytopathy showing the paradoxical essentiality of nitric oxide in the pathogenesis of IBDV.

\section{Acknowledgments \\ BG acknowledges the financial support received during part of this study in the form of a Senior Research Fellowship [Ref No. 20-06/2010(i)EU-IV] from Council of Scientific and Industrial Research, India. \\ Funding \\ This work was supported by the Directorate of Experimentation, G. B. Pant University of Agriculture \& Technology, India.}

\section{Availability of data and materials}

The data generated or analyzed during the current study are available from the corresponding author on reasonable request.

\section{Authors' contributions}

BG performed the experiments, analyzed the results and drafted the manuscript. $\mathrm{VU}$ conceived the study and participated in analysis of results. SKR designed the experiments and revised the manuscript. All authors read and approved the final manuscript.

Ethics approval and consent to participate

Not applicable.

Consent for publication

Not applicable.

\section{Competing interests}

The authors declare that they have no competing interests.

\section{Publisher's Note}

Springer Nature remains neutral with regard to jurisdictional claims in published maps and institutional affiliations.

\section{Author details \\ ${ }^{1}$ Animal Biotechnology Center, Department of Veterinary Physiology and Biochemistry, College of Veterinary \& Animal Sciences, G. B. Pant University of Agriculture \& Technology, Pantnagar 263145, India. ${ }^{2}$ Clinical Research Division, Ayurvet Limited, Katha 173205, India. ${ }^{3}$ Division of Animal Biochemistry, FMD Research Laboratory, Indian Veterinary Research Institute, Hebbal, Bengaluru 560024, India.}

Received: 11 August 2017 Accepted: 8 December 2017

Published online: 08 January 2018

\section{References}

1. Akarid K, Sinet M, Desforges B, Gougerot-Pocidalo MA. Inhibitory effect of nitric oxide on the replication of a murine retrovirus in. Avian Pathology. 1995:8:205-12.

2. Akerstrom S, Mousavi-Jazi M, Klingstrom J, Leijon M, Lundkvist A, Mirazimi A Nitric oxide inhibits the replication cycle of severe acute respiratory syndrome coronavirus. J Virol. 2004;79:1966-9.

3. Ali-Ahmad D, Bonville CA, Rosenberg HF, Domachowsxe JB. Replication of respiratory syncytial virus is inhibited in target cells generating nitric oxide in situ. Front Biosci. 2003;8:a48-53.

4. Ashraf S. Studies on Infectious Bursal Disease virus, Thesis, Ph.D. USA: Graduate School of the Ohio State University; 2005.

5. Bi Z, Reiss CS. Inhibition of vesicular stomatitis virus infection by nitric oxide. I Virol. 1995:69:2208-13.

6. Cao W, Baniecki ML, McGrath WJ, Bao C, Deming CB, Rade JJ, Lowenstein CJ, Mangel WF. Nitric oxide inhibits the adenovirus proteinase in vitro and viral infectivity in vivo. FASEB J. 2003;17:2345-6.

7. Croen KD. Evidence for an antiviral effect of nitric oxide: inhibition of herpes simplex virus type-1 replication. J Clin Investig. 1993;91:2446-52.

8. Dalton RM, Rodríguez JF. Rescue of Infectious Birnavirus from recombinant ribonucleoprotein complexes. PLoS One. 2014;9:e87790. 
9. Eterradossi, N. and Saif, Y.M. (2013). Infectious Bursal Disease. In: Swayne, D. E.; Glisson, J.R.; McDougald, L.R.; Nolan, L.K.; Suarez, D.L. and Nair, V. Eds. Diseases of poultry 13th edn. Wiley-Blackwell. Pp. 219-246.

10. Freshney RI. MTT assay. In: Culture of animal cells: a manual of basic technique $4^{\text {th }}$ edn: Wiley-Liss; 2000. p. 536-7.

11. Ganguly B. Effect of hydroalcoholic extract of Withania somnifera (Ashwagandha) on growth kinetics of Infectious Bursal Disease virus in chicken embryo fibroblast culture, Thesis, M.V.Sc. India: G.B. Pant University of Agriculture and Technology; 2009.

12. Ganguly B, Kumar N, Ahmad AH, Rastogi SK. Influence of phytochemical composition on in vitro antioxidant and reducing activities of Indian ginseng [Withania somnifera (L.) Dunal] root extracts. Journal of Ginseng Research. 2017; https://doi.org/10.1016/j.jgr.2017.05.002.

13. Gao X, Tajima M, Sairenji T. Nitric oxide down-regulates Epstein-Barr virus reactivation in epithelial cell lines. Virology. 1999;258:375-81.

14. Guillemard E, Geniteau-Legendre M, Kergot R, Lemaire G, Petit JF, Labarre C, Quero AM. Activity of nitric-oxide generating compounds against Encephalomyocarditis virus. Antimicrob Agents Chemother. 1996;40:1057-9.

15. Harris N, Buller RM, Karupiah G. Gamma interferon induced, nitric oxidemediated inhibition of vaccinia virus replication. J Virol. 1995;69:910-5.

16. Iuvone T, Esposito G, Capasso F, Izzo AA. Induction of nitric oxide synthase expression by Withania somnifera in macrophages. Life Sci. 2003; $72(14): 1617-25$

17. Jena S. Effect of nitric oxide on the in vitro replication kinetics of Infectious Bursal Disease virus. In: Thesis, M.V.Sc. India: G.B. Pant University of Agriculture and Technology; 2008.

18. Khatri M, Sharma JM. Infectious Bursal Disease virus infection induces macrophage activation via p38 MAPK and NF-KB pathways. Virus Res. 2006;118:70-7.

19. Khatri M, Palmquist JM, Cha RM, Sharma JM. Infection and activation of bursal macrophages by virulent Infectious Bursal Disease virus. Virus Res. 2005;113:44-50.

20. Lin YL, Huang YL, Ma SH, Yeh CT, Chiou SY, Chen LK, Liao CL. Inhibition of Japanese encephalitis virus infection by nitric oxide: antiviral effect of NO on RNA virus replication. J Virol. 1997;71:5227-35.

21. Nilsson BO. Biological effects of aminoguanidine: an update. Inflamm Res. 1999:48:509-15

22. Padalko E, Ohnishi T, Matsushita K, Sun H, Fox-Talbot K, Bao C, Baldwin WMIII, Lowenstein CJ. Peroxynitrite inhibition of coxsackievirus infection by prevention of viral RNA entry. Proc Natl Acad Sci U S A. 2004;101:11731-6.

23. Takhampunya R, Padmanabhan R, Ubol S. Antiviral action of nitric oxide on dengue virus type 2 replication. J Gen Virol. 2006;87(10):3003-11.

24. Villegas P. Preparation of chicken embryo fibroblast (CEF) cell cultures. In: Avian virus diseases laboratory manual. Georgia University; 2006. p. 3.

25. Yamaguchi, T.; Ogawa, M.; Inoshima, Y; Miyoshi, M.; Fukushi, H. and Hirai, K. (1996). Identification of sequence changes responsible for the attenuation of highly virulent Infectious Bursal Disease virus. Virology 223, 219-223.

26. Zaragoza C, Ocampo CJ, Saura M, Bao C, Leppo M, Lafondwalker A, Thiemann DR, Hruban R, Lowenstein CJ. Inducible nitric oxide synthase protection against coxsackievirus pancreatitis. J Immunol. 1999;163:5497-504.

27. Zheng $X$, Karel AS. Inhibitory effect of nitric oxide and gamma interferon on in vitro and in vivo replication of Marek's disease virus. J Virol. 2000;74:3605-12.

\section{Submit your next manuscript to BioMed Central and we will help you at every step:}

- We accept pre-submission inquiries

- Our selector tool helps you to find the most relevant journal

- We provide round the clock customer support

- Convenient online submission

- Thorough peer review

- Inclusion in PubMed and all major indexing services

- Maximum visibility for your research

Submit your manuscript at www.biomedcentral.com/submit

Biomed Central 